\title{
Recent Environmental Changes in the Arctic: A Review
}

\author{
JAMES MORISON,,$^{1,2}$ KNUT AAGAARD ${ }^{1}$ and MIKE STEELE ${ }^{1}$
}

\author{
(Received 22 February 1999; accepted in revised form 5 September 1999)
}

\begin{abstract}
Numerous recent observations indicate that the Arctic is undergoing a significant change. In the last decade, the hydrography of the Arctic Ocean has shifted, and the atmospheric circulation has undergone a change from the lower stratosphere to the surface. Typically the eastern Arctic Ocean, on the European side of the Lomonosov Ridge, is dominated by water of Atlantic origin. A cold halocline of varying thickness overlies the warmer Atlantic water and isolates it from the sea ice and surface mixed layer. The western Arctic Ocean, on the North American side of the Lomonosov Ridge, is characterized by an added layer of water from the Pacific immediately below the surface mixed layer. Data collected during several cruises from 1991 to 1995 indicate that in the 1990s the boundary between these eastern and western halocline types shifted from a position roughly parallel to the Lomonosov Ridge to near alignment with the Alpha and Mendeleyev Ridges. The Atlantic Water temperature has also increased, and the cold halocline has become thinner. The change has resulted in increased surface salinity in the Makarov Basin. Recent results suggest that the change also includes decreased surface salinity and greater summer ice melt in the Beaufort Sea. Atmospheric pressure fields and ice drift data show that the whole patterns of atmospheric pressure and ice drift for the early 1990s were shifted counterclockwise $40^{\circ}-60^{\circ}$ from earlier patterns. The shift in atmospheric circulation seems related to the Arctic Oscillation in the Northern Hemisphere atmospheric pressure pattern. The changes in the ocean circulation, ice drift, air temperatures, and permafrost can be explained as responses to the Arctic Oscillation, as can changes in air temperatures over the Russian Arctic.
\end{abstract}

Key words: Arctic, Arctic Ocean, Arctic Oscillation, climate change

RÉSUMÉ. De nombreuses observations effectuées récemment indiquent qu'un changement majeur est en train de se produire dans l'Arctique. Au cours des dix dernières années, l'hydrographie de l'océan Arctique s'est déplacée et la circulation atmosphérique a subi un changement, de la basse stratosphère à la surface. En général, l'océan Arctique oriental, du côté européen de la dorsale Lomonosov, est dominé par l'eau d'origine atlantique. Une halocline froide d'épaisseur variable est sus-jacente à l'eau atlantique plus chaude et l'isole de la glace marine et de la couche mixte de surface. L'océan Arctique occidental, du côté nord-américain de la dorsale Lomonosov, se caractérise par une couche supplémentaire d'eau du Pacifique située juste au-dessous de la couche mixte de surface. Les données recueillies au cours de plusieurs croisières de 1991 à 1995 indiquent que, dans les années 1990 la limite entre ces types d'haloclines de l'est et de l'ouest est passée d'une position plus ou moins parallèle à la dorsale Lomonosov, à un alignement presque parfait avec les dorsales Alpha et Mendeleyev. La température des eaux de l'Atlantique a également augmenté, et l'halocline froide s'est amincie. Ce changement a amené une augmentation de la salinité de surface dans le bassin de Makarov. De récents résultats suggèrent que le changement s'accompagne d'une diminution de la salinité de surface et d'une augmentation de la fonte estivale de la glace dans la mer de Beaufort. Les données barométriques et celles de la dérive des glaces montrent que tous les schémas de pression atmosphérique et de dérive des glaces pour les premières années de 1990 se sont déplacés de 40 à $60^{\circ}$ par rapport aux précédents. Le déplacement dans la circulation atmosphérique semble lié à l'oscillation arctique dans le schéma de pression atmosphérique de l'hémisphère Nord. Les changements dans la circulation océanique, la dérive des glaces, la température de l'air et le pergélisol peuvent s'expliquer comme une réponse à l'oscillation arctique, tout comme les changements dans la température de l'air au-dessus de l'Arctique russe.

Mots clés: Arctique, océan Arctique, oscillation arctique, changement climatique

Traduit pour la revue Arctic par Nésida Loyer.

\section{INTRODUCTION}

During the past decade, scientists have argued that the Arctic may be a sensitive indicator of global change. They have cited such modeling studies as Manabe et al. (1991), Manabe and Stouffer (1994), and Rind et al. (1995). Manabe et al. (1991) indicate that under a representative global warming scenario, temperature increases will be amplified in the Arctic, and enhanced precipitation at high latitudes will cause a decrease in upper Arctic Ocean salinity. Rind et al. (1995) suggest that the pattern of warming in the Arctic may be a sensitive indicator of anthropogenic global warming. In the 1980s these arguments were hypothetical, since our view of the Arctic was

\footnotetext{
${ }^{1}$ Polar Science Center, Applied Physics Laboratory, University of Washington, Seattle, Washington 98105, U.S.A.

${ }^{2}$ Corresponding author: morison@apl.washington.edu

(C) The Arctic Institute of North America
} 
still largely a static one. Now this has changed, and we are seeing evidence of major shifts in the Arctic environment. Serreze et al. (2000) review evidence of recent change with emphasis on atmospheric and terrestrial observations. Here we review changes in the ocean and their connection to changes in the atmosphere. We will see that the influence of Atlantic Water in the Arctic Ocean has become more widespread and intense, that the pattern of ice drift has shifted, and that the atmospheric circulation has changed from top to bottom. We will also suggest how these changes may be connected. It is unknown whether the observed changes are consequences of global greenhouse warming. However, they give clues to understanding the connections between the Arctic and the rest of the planet, especially because the various changes stand out in such sharp contrast to earlier observations and appear to interact. The changes observed in the Arctic provide an opportunity to test our understanding of how climate and the Arctic system function. Conceivably the changes are also indicators of more pervasive alterations in the global environment.

\section{CHANGES IN THE OCEAN}

In the last few years, changes have become apparent in the hydrography of the Arctic Ocean. The results of several recent expeditions indicate that the presence of Atlantic-derived water in the Arctic has increased. Data collected from the U.S.S. Pargo (Morison et al., 1998a) and the Henry Larsen in 1993 (Carmack et al., 1995; McLaughlin et al., 1996), the Polar Sea and the Louis S. St. Laurent (Carmack et al., 1997) in 1994, and the U.S.S. Cavalla in 1995 (Steele and Boyd, 1998) all indicate that the boundary between the eastern (Atlantic) and western (Pacific) halocline types has moved. Earlier it was approximately aligned with the Lomonosov Ridge, but now it lies roughly over the Alpha and Mendeleyev Ridges. The area occupied by the eastern water types is therefore nearly $20 \%$ greater than previously observed. The greater Atlantic influence is also manifest in warm cores observed over the Lomonosov and Mendeleyev Ridges in the U.S.S. Pargo and St. Laurent data: temperatures over the Lomonosov Ridge were higher than $1.5^{\circ} \mathrm{C}$. Carmack et al. (1995) and McLaughlin et al. (1996) also observed an Atlantic layer temperature increase over the Mendeleyev Ridge. The earlier data of Gorshkov (1983) and Treshnikov (1977) give no indication of such warm cores over the Mendeleyev Ridge and show a temperature nearly $1{ }^{\circ} \mathrm{C}$ colder over the Lomonosov Ridge. The recently prepared digital atlas of Russian hydrographic data (EWG, 1997) confirms that no temperatures greater than $1{ }^{\circ} \mathrm{C}$ were observed during numerous investigations between 1950 and 1989.

Figures 1-3 illustrate the differences between temperature and salinity measured in the fall of 1993 from the U.S.S. Pargo (Morison et al., 1998a) and climatological temperature and salinity from the Joint U.S.-Russian Atlas of the Arctic Ocean: Winter Period (EWG, 1997; Gore and Belt, 1997). The EWG atlas (EWG, 1997) is a compilation of Russian and Western wintertime hydrographic data taken from 1948 to 1987 . The data have been objectively gridded and separated into decadal and total statistics. For our comparison, the temperature and salinity from the Atlas have been interpolated to the cruise track of the U.S.S. Pargo, illustrated in Figure 1. The Pargo data were gathered with two types of instrument: a time-tested, internally recording Conductivity, Temperature, Depth (CTD) instrument with an accuracy of at least 0.01 in salinity and $0.01^{\circ} \mathrm{C}$ in temperature, and novel expendable CTDs with accuracies of about 0.1 in salinity and $0.1^{\circ} \mathrm{C}$ in temperature (Morison et al., 1998a). The EWG (1997) data come from many sources over many years, but the accuracy given by EWG is better than 0.02 in salinity and $0.01^{\circ} \mathrm{C}$ in temperature. An additional problem with the EWG data, as with any atlas, is representing data gathered over a wide range of times, places, and depths. Thus, the best demonstration of the EWG data is how well they compare to the Pargo data in the large regions that show no change.

The differences between 1993 and the EWG (1997) climatology are plotted as color contours along the U.S.S. Pargo track in the three-dimensional views of Figures 2 and 3. Figure 2 shows that the salinity in the upper $250 \mathrm{~m}$ has increased dramatically in a wedge extending to a front roughly aligned with the Alpha and Mendeleyev Ridges. Climatologies (Levitus, 1982; Gorshkov, 1983; EWG, 1997) indicate that this front was more nearly aligned with the Lomonosov Ridge in the past (Figs. 2, 3). The position of the front between the saltier surface waters of the eastern Arctic and the fresher western Arctic waters has advanced about $40^{\circ}$ of longitude across the Makarov Basin. As a result, the presence of Atlantic-derived water in the basin has increased, and the surface salinity in the Makarov has increased 2.50. This increase is likely a conservative estimate in the uppermost layers because the EWG data represent winter conditions, while the Pargo data are from late summer and early fall, when the surface layers would normally be fresher. This summer-winter difference is likely part of the reason for the negative salinity difference shown for the surface waters of the Canadian Basin. The salinity increase in the Makarov Basin is comparable to the spatial variability of salinity over the whole upper Arctic Ocean. Comparison with statistics in the EWG atlas also indicates that the change is several times the typical interannual variability in the Makarov Basin. Furthermore, Steele and Boyd (1998) find that the Eurasian Basin winter mixed layer was saltier during the early 1990s than at any time in the 40-year span of the EWG atlas.

Figure 3 shows that temperature has also increased in the warm core of Atlantic water over the Lomonosov Ridge, with the maximum temperature over $1^{\circ} \mathrm{C}$ greater than at any time in the observed past. Furthermore, the Atlantic layer is shallower than in the past, so that the temperature is over $2^{\circ} \mathrm{C}$ greater at $200 \mathrm{~m}$. A less intense 


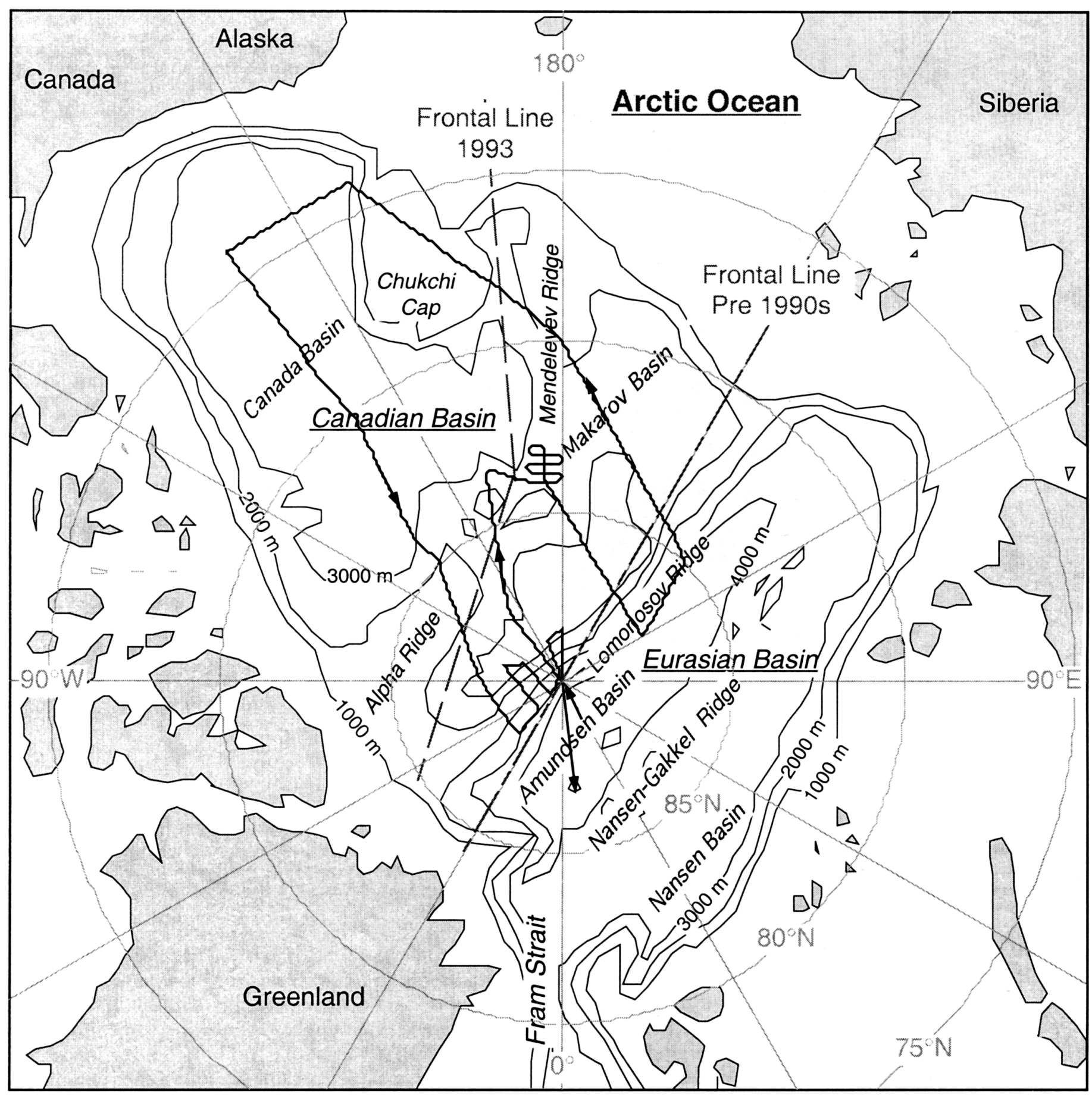

FIG. 1. The Arctic Ocean. The Arctic Ocean is divided by the Lomonosov Ridge into two major basins, the Eurasian and Canadian. These basins are often considered the eastern Arctic and western Arctic, respectively. The Canadian Basin is divided into the Canada and Makarov sub-basins by the Alpha and Mendeleyev ridge system. The Eurasian Basin is divided into the Nansen and Amundsen sub-basins by the Nansen-Gakkel Ridge. The cruise track of the U.S.S. Pargo in AugustSeptember 1993 is shown for comparison with Figures 2 and 3. The frontal line between eastern and western upper ocean water types is shown in its pre-1990s position (roughly along $150^{\circ} \mathrm{E}$ ) and in its 1993 position (roughly along $170^{\circ} \mathrm{W}$ ).

warm core appears over the Mendeleyev Ridge, and there is a general warming in the Makarov Basin centered near $200 \mathrm{~m}$. The slight cooling centered at about $100 \mathrm{~m}$ in the Makarov Basin is associated with the influx of more saline water from the Eurasian Basin. These observations suggest that the whole Makarov Basin has taken on a more Atlantic character. Furthermore, the extent of the Bering
Sea water temperature maximum has retreated behind the advancing Atlantic water front. Decadal statistics from the EWG atlas indicate that this change is greater than the normal variability. We add that the cooling below $200 \mathrm{~m}$ in the Canada Basin is due to a $25-50 \mathrm{~m}$ downward displacement of the thermocline in the Pargo data relative to the EWG climatology. 


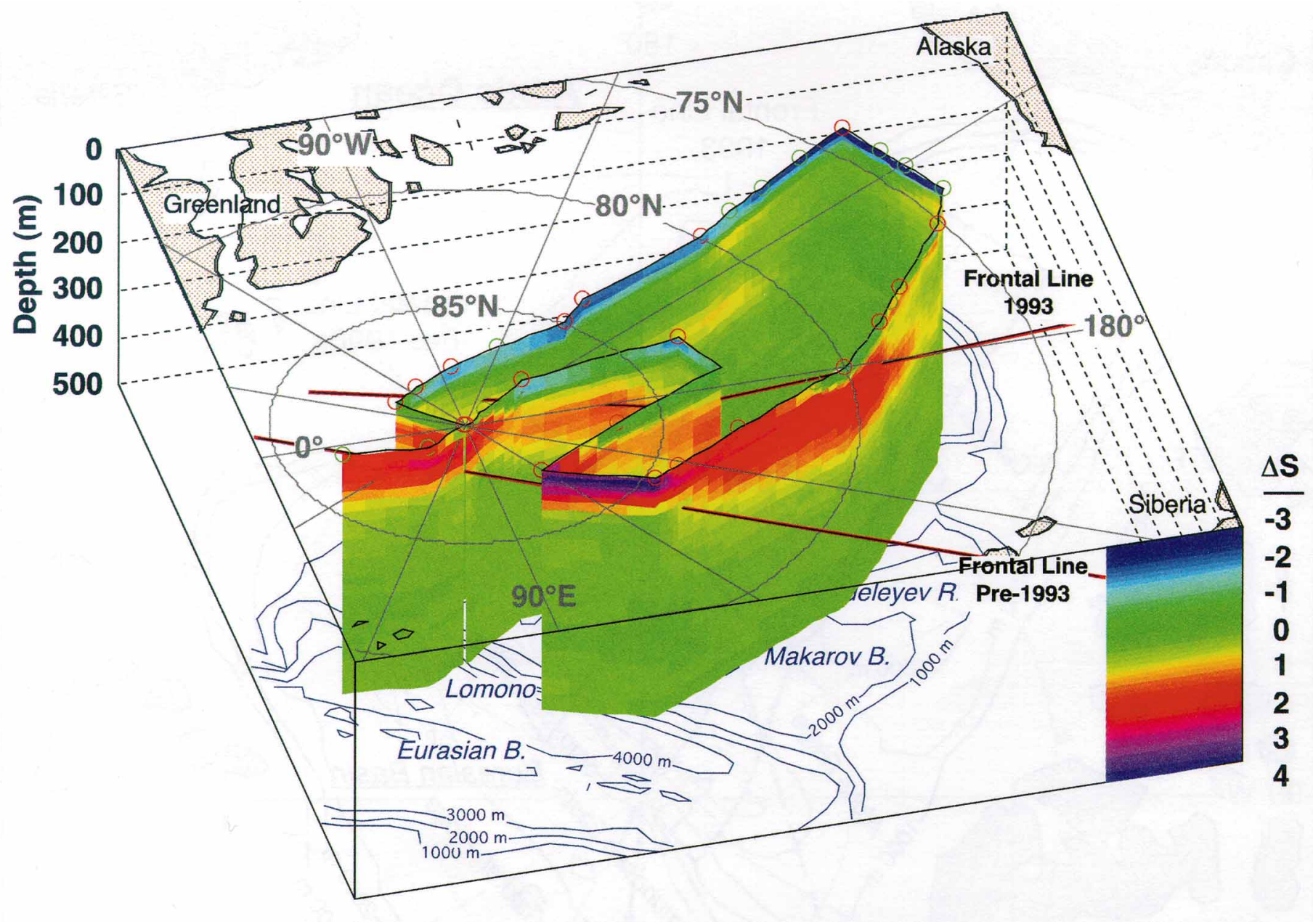

FIG. 2. Contours showing the salinity measured during the 1993 SCICEX cruise (Morison et al., 1998a), minus the climatological salinity from the EWG Joint U.S.Russian Atlas (EWG, 1997), interpolated to the SCICEX '93 cruise track. The largest difference is due to the shift in the front between Atlantic- and Pacificdominated waters. The front used to lie over the Lomonsov Ridge. It now lies roughly over the Alpha and Mendeleyev Ridges, as indicated by the red-and-black line. The frontal shift results in a $2.5 \%$ increase in salinity in the upper $200 \mathrm{~m}$ of the Makarov Basin.

Pawlowicz and Farmer (1997) compare modern data with historical data from the Greenland-Ellesmere Island region of the Arctic Ocean. They show that while large temperature changes have occurred over the Lomonosov Ridge over the last decade, the temperature gradient over the eastern end of the Alpha Ridge in the Canadian Basin is fairly small, and temperatures there have shown little interannual change over a 40 -year period up to the early 1990s. These facts suggest that the change in ocean properties is most pronounced in eastern longitudes.

The extensive data gathered during the Arctic Ocean Section (AOS) of 1994 (Carmack et al., 1997; Swift et al., 1997) give a measure of the timing, depth, and breadth of the change in ocean structure, particularly the warming of the Atlantic water. The warming in the Atlantic layer represents more than a simple increase of the temperature maximum. Comparison of the 1994 data gathered over the Eurasian slope of the Lomonosov Ridge with data from the same area gathered during the Oden cruise in 1991 shows that the temperature maximum has become both warmer and shallower, and that the warming is also seen from the top of the thermocline to depths below $1500 \mathrm{~m}$. The temperature gradient in the thermocline is therefore also greater in the 1994 data.

One of the most remarkable aspects of the AOS observations is the geographic distribution of warm Atlantic water that they disclose. The observations extend from the Chukchi boundary of the Canadian Basin to the central Nansen Basin. Besides the temperature maximum encountered over the Lomonosov Ridge, temperature maxima near $1^{\circ} \mathrm{C}$ were observed at four places over the Chukchi boundary and Mendeleyev Ridge. This region has been visited so rarely in the past that it is difficult to know precisely the amount of the warming, but it is at least $0.2^{\circ} \mathrm{C}$. The position of the warm cores suggests that the Atlantic water moves with a barotropic flow following the isobaths along the slopes and ridges, and that the warm water is a tracer that is carried along by this flow. Swift et 


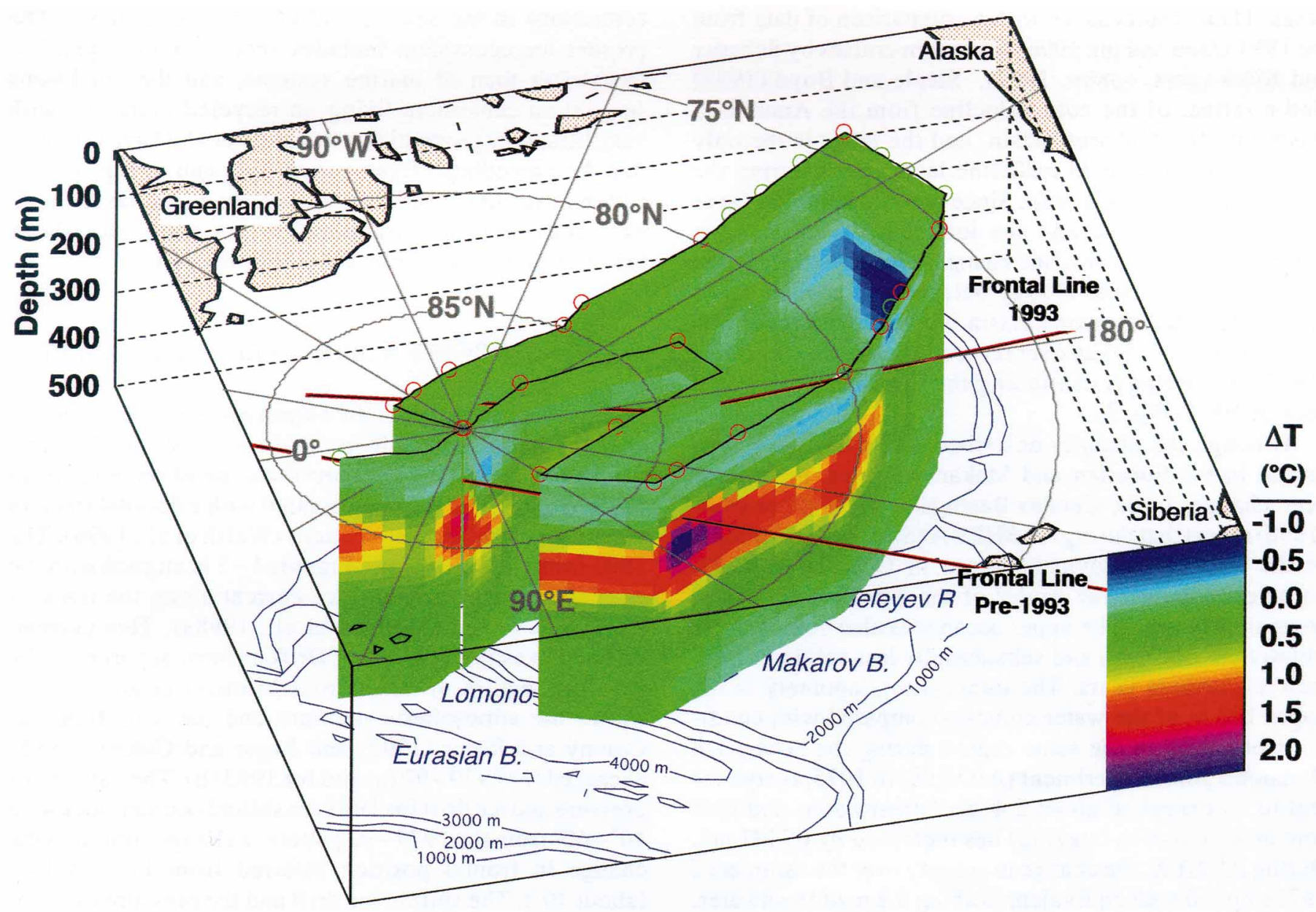

FIG. 3. Contours showing the temperature measured during the 1993 SCICEX cruise (Morison et al., 1998a), minus the climatological temperature from the EWG Joint U.S.-Russian Atlas (EWG, 1997), interpolated to the SCICEX ' 93 cruise track. The $200 \mathrm{~m}$ temperature is increased in the Makarov Basin region affected by the frontal shift described in Figure 1. The largest difference is due to the appearance of warm cores over the Lomonosov and Mendeleyev Ridges: the result is an increase of over $1.5^{\circ} \mathrm{C}$ in the temperature maximum of the Atlantic Water. Over the Lomonosov Ridge, the core of the Atlantic Water is now at a shallower depth, resulting in a temperature increase of over $2^{\circ} \mathrm{C}$ at around $200 \mathrm{~m}$ depth.

al. (1997) use the temperature as a tracer to infer the connection to the temperature of the Atlantic water inflow through Fram Strait. Estimating the time at which the Atlantic water entered Fram Strait at various locations, and comparing the phase-shifted core temperatures with those actually measured near Fram Strait, they argue that the warming in the Arctic Basin is due to changes in the Atlantic water inflow temperature.

The observed salinity and temperature changes appear to have begun in the late 1980s. The differences from climatology as illustrated by Figures 2 and 3 are too large and spatially consistent to be attributed to instrument error or normal seasonal and interannual variability (Grotefendt et al., 1998). Data from the Oden cruise in 1991 (Anderson et al., 1994; Rudels et al., 1994) show a slight warming near the Pole, and Quadfasel (1991) reports warmer than usual temperatures in the Atlantic Water inflow in 1990, but the differences from climatology seen during the sub- sequent cruises are much larger. Comparison of the sigmatheta profiles from the 1991 Oden and 1994 AOS cruises (Carmack et al., 1997; Swift et al., 1997) indicates that the Atlantic water from 200 to $1500 \mathrm{~m}$ was less dense in 1994 than in 1991, and the large differences between the 1991 and 1994 data suggest that we are seeing an event unique to the 1990s.

Even more recent observations reveal other aspects of the change that involve consequences for the thermodynamic balance of the Arctic Ocean. The shoaling of the Atlantic water discussed above suggests that the halocline, which isolates the surface from the warm Atlantic water, is growing thinner. Steele and Boyd (1998) show from observations during the 1995 cruise of the U.S.S. Cavalla that the cold halocline is indeed continuing to thin. They compare Arctic Ocean hydrographic data sets from the 1990s and the EWG atlas (EWG, 1997), showing that the Eurasian Basin cold halocline layer has retreated during 
the 1990s to cover significantly less area than in previous years. Their results agree with a comparison of data from the 1991 Oden and the 1996 Polarstern cruises by Schauer and Björk (pers. comm. 1997). Steele and Boyd (1998) find a retreat of the cold halocline from the Amundsen Basin into the Makarov Basin, and the latter is the only region with a true cold halocline layer found during the cruise of the U.S.S. Cavalla. Since the cold halocline layer insulates the surface and sea ice from the heat of the Atlantic water, the halocline changes could have profound effects on the surface energy balance and sea ice in the Arctic. The mid-Eurasian Basin winter mixed layer was also saltier in 1995 than ever recorded in the 40-year EWG (1997) climatology, continuing the Eurasian Basin trend seen in 1993 (Fig. 2).

Although the changes described so far have been observed in the Eurasian and Makarov Basins, there have been changes in the Canada Basin as well. McPhee et al. (1998) report that during the SHEBA (Surface Heat Budget of the Arctic) deployment phase in October of 1997, multiyear ice near the center of the Beaufort Gyre was anomalously thin. The upper ocean was also both warmer (relative to freezing) and substantially less saline in 1997 than in previous years. The total salinity anomaly in the upper $100 \mathrm{~m}$ of the water column, compared with conditions observed in the same region during the Arctic Ice Dynamics Joint Experiment (AIDJEX) in 1975, is equivalent to an excess of about $2.4 \mathrm{~m}$ of freshwater, and heat content (relative to freezing) has increased by $67 \mathrm{MJ} \mathrm{m}^{-2}$. During AIDJEX, the change in salinity over the summer of 1975 implied melt equivalent to about $0.8 \mathrm{~m}$ of freshwater. Analogy with the seasonal progression observed during AIDJEX suggests that up to $2 \mathrm{~m}$ of freshwater input may have occurred during the 1997 summer, but from salinity changes alone we cannot distinguish between changes in ice melt and runoff. The increased heat content, combined with the thin ice, does suggest that during the summer of 1997 the ice concentration was low enough to allow more solar radiation to enter the upper ocean. McPhee et al. (1998) argue that these effects may be due to reduced ice convergence in the Beaufort Sea.

The oxygen isotope ratio $\left(\delta^{18} \mathrm{O}\right)$ and barium $(\mathrm{Ba})$ concentration measurements of Macdonald et al. (1999) suggest that a significant amount ( 40\%) of the 1997 freshening at the SHEBA site is due to river runoff from the Mackenzie River. They also indicate that the percentage of runoff was even greater farther south in the Beaufort Sea. A time series of observations shows a jump in the amount of seaice melt in the early 1990s coinciding with other changes we discuss here.

Melnikov et al. (1998) report that the physical changes in the upper ocean have caused dramatic differences in the biology of the SHEBA region as well. A comparison of SHEBA data and Soviet observations of 20 years ago on sea ice and the upper water column shows a marked decrease in larger diatoms and microfauna within the ice interior, a large increase in freshwater algae within the ice interior, and lower chlorophyll and nitrate-nitrogen concentrations in the sea ice and upper water column. The present ice ecosystem includes species more typical of freshwater than of marine systems, and the conditions suggest an ecosystem living on recycled nutrients, with very little new production. Melnikov et al. (1998) suggest that the exceedingly fresh mixed layer and strong stratification have cut off the ice and shallow mixed layer for an extended time from nutrients below, leaving a brackish sea ice ecosystem existing on recycled nitrogen.

\section{CHANGES IN THE ATMOSPHERE AND ICE DRIFT}

The changes in the Arctic Ocean appear to be related to changes in the atmosphere. Morison et al. (1998a) and Steele and Boyd (1998) suggest that the observed shift in ocean frontal position is associated with a decadal trend in the atmospheric pressure pattern (Walsh et al., 1996). The 1993 frontal line shown in Figures 1-3 is aligned with the dominant geostrophic surface current along the track of the U.S.S. Pargo (Morison et al., 1998a). This current, referred to as the Transpolar Drift, is most apparent in the ice drift. Figure 4, taken from Morison et al. (1998a), shows the atmospheric pressure and ice drift fields of Colony and Rigor (1993) and Rigor and Colony (1995) averaged for 1979-92 (a) and for 1993 (b). The patterns of pressure and ice drift for 1993 are shifted counterclockwise $40^{\circ}-60^{\circ}$ from the $1979-92$ pattern, a change similar to the change in frontal position inferred from Figures 1-3 (about $40^{\circ}$ ). The shift in ice drift and the pressure fields of 1993 is consistent with the average fields for 1988-96 compared to 1979-87 (Steele and Boyd, 1998).

The yearly average pressure maps of the International Arctic Buoy Program (IABP) indicate that the shift in the atmospheric pressure pattern began around $1988-89$. Before that time, the Beaufort high was usually centered over $180^{\circ}$ longitude, but after 1988 the annual average Beaufort high was weaker and usually confined to western longitudes. This change is consistent with the findings of Walsh et al. (1996) that the annual mean atmospheric surface pressure in the Polar Basin is decreasing and has been below the 1979-95 mean in every year since 1988 . This decrease has been attended by sharp increases in cyclone frequency over the central Arctic Ocean (Serreze et al., 1997). The time of the shift in the atmosphere corresponds approximately to our estimate of when the ocean changes began. Morison et al. (1998a) suggest that the atmosphere might in part drive the observed changes in ocean circulation by Ekman pumping, and that the effect of these circulation changes may reach deeper with time.

Maslanik et al. (1998) give consistent evidence of the change in ice drift as related to atmospheric circulation changes. Comparison of mean ice transport patterns for 1989-96 estimated from satellite microwave imagery show the contraction of the Beaufort Gyre and shift of the transpolar drift relative to conditions during 1979-88. 

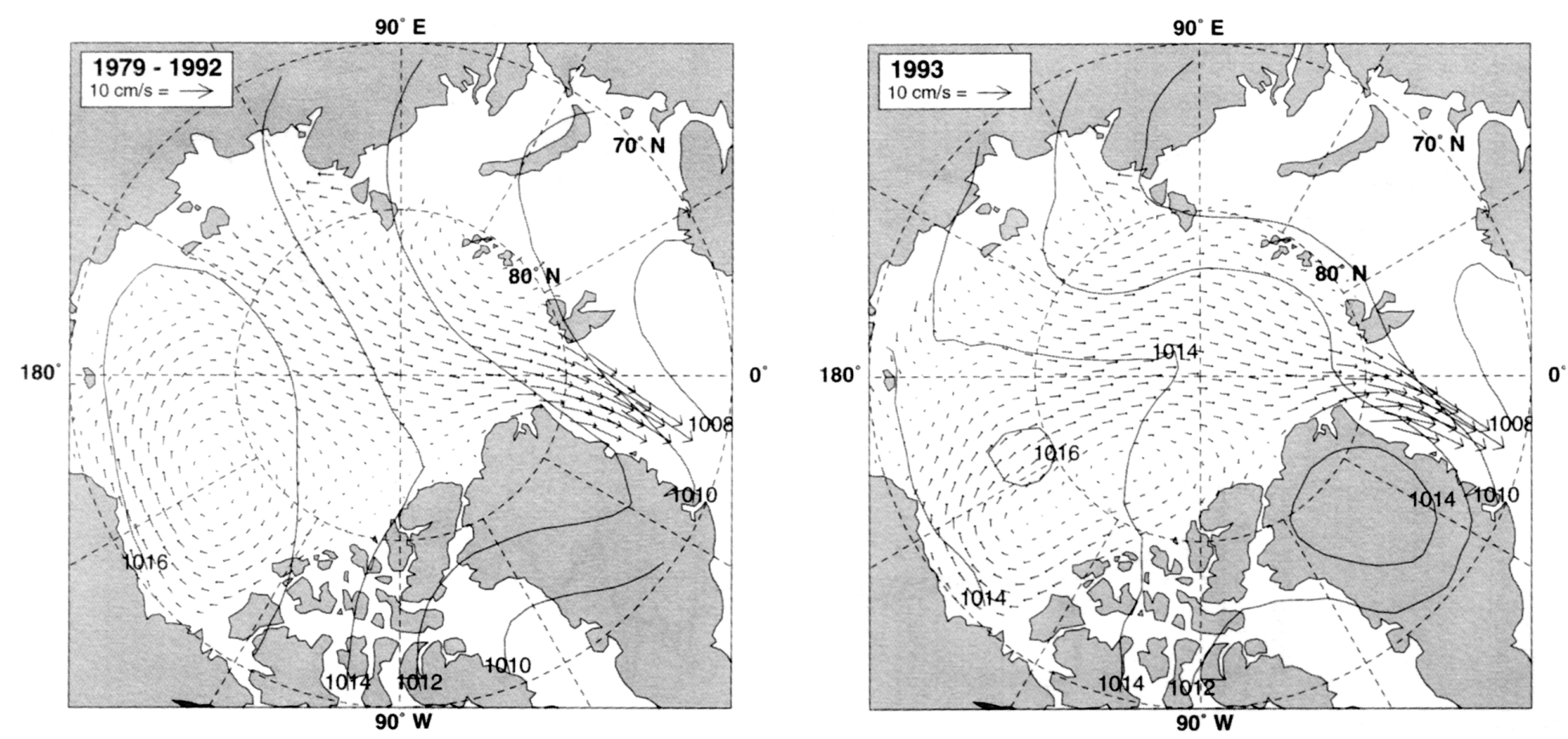

FIG. 4. a) Average surface atmospheric pressure and sea ice drift velocities from 1979 to 1992. The figure is from Figure 11a of Morison et al. (1998a). The data are from the International Arctic Buoy Program (Colony and Rigor, 1993) and courtesy of Ignatius Rigor. b) Average surface atmospheric pressure and sea ice drift velocities for 1993. The figure is from Figure 11b of Morison et al. (1998a). The data are from the International Arctic Buoy Program (Rigor and Colony, 1995) and courtesy of Ignatius Rigor. Note that the pressure and drift patterns are shifted counter-clockwise in the Beaufort Sea relative to the 1979-92 patterns.

They examine the relation of this change to the North Atlantic Oscillation (NAO) index. (The NAO index, calculated as the difference between sea level pressures at Lisbon, Portugal, and at Stykkisholmor, Iceland, has been seen as a key climate indicator, particularly for the Atlantic Ocean and Eurasian Continent.) Maslanik et al. (1998) indicate that the change in ice drift pattern has occurred in conjunction with the positive NAO index since 1989. However, in earlier years of positive NAO this was not always the case, suggesting that the low arctic sea level pressure of the 1990s is a critical ingredient in the circulation change. In the three years since 1989 that had both the strongest positive NAO index and low arctic sea level pressure, the ice transports through Fram Strait were twice the transports in the three years during 1978-96 that had the most negative NAO index.

Several modeling efforts have shown features of the Arctic Ocean changing in response to realistic atmospheric forcing. Using an ocean model run with atmospheric forcing over the last 50 years, Proshutinsky and Johnson (1997) report two decadally varying regimes corresponding to anticyclonic and cyclonic circulations of the arctic atmosphere and ocean. The anticyclonic circulations correspond to a "cold and dry" atmosphere and a "cold and salty" ocean; the cyclonic, to a "warm and wet" atmosphere and a "warm and fresh" ocean. Shifts from one regime to another are forced by changes in location and intensity of the Icelandic low and the Siberian high. Maslanik et al. (1998) indicate that the ice transport patterns associated with positive and negative NAO resemble weak versions of the cyclonic and anticyclonic modes of ice drift modeled by Proshutinsky and Johnson (1997).
Proshutinsky and Johnson (1997) report that the winddriven motions of ice and water in the Arctic alternate between anticyclonic and cyclonic circulation states, with each regime persisting for $5-7$ years (the period is $10-15$ years). Their arguments suggest that the recent change in the Arctic is an extreme expression of a cyclonic pattern.

The simulations of Zhang et al. (1998) indicate a strengthened inflow of Atlantic waters through the Barents Sea in recent years. The ice-ocean simulation of the past 18 years is driven by daily varying winds and air temperatures. It shows significant warming and salinization beginning in 1989, due mainly to a marked increase in the inflow of Atlantic water across the Barents Sea shelf. The result is a warming of the Atlantic layer within the Arctic Ocean, a weakening of the halocline in the eastern Arctic, and a decrease in sea ice volume and extent.

Zhang and Hunke (in press) report on simulations with the Parallel Ocean Program (POP) of Los Alamos National Laboratory, which has been adapted to the Arctic Ocean. Simulated surface distributions of tracers under conditions representative of the first half of the 1990s show the Beaufort Gyre significantly decreased in extent. The simulation also shows the central Arctic having a cyclonic circulation similar to that discussed by Proshutinsky and Johnson $(1996,1997)$. The Transpolar Drift is absent over the Lomonosov Ridge, having been shifted over the Mendeleyev and Alpha Ridges. Maslowski et al. (1998) describe similar results from their coupled Arctic Ocean model and a high-resolution global ocean model. Their modeled response to $1979-93$ winds is similar to the observed ocean changes. Taken together, these models suggest that in the 1990s, most of the water on the Russian 
a)

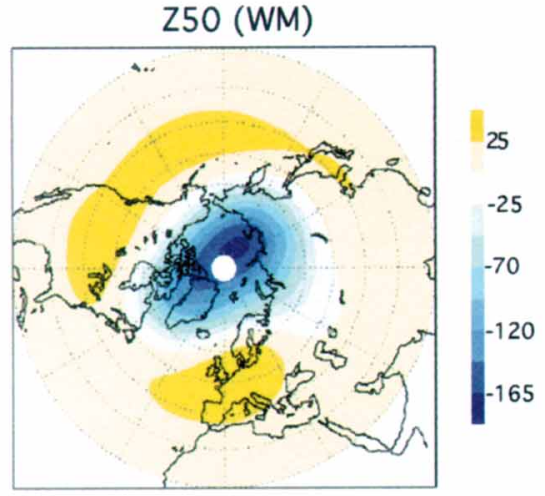

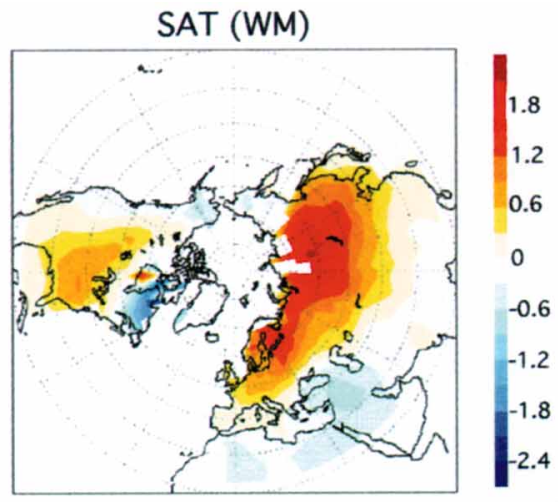

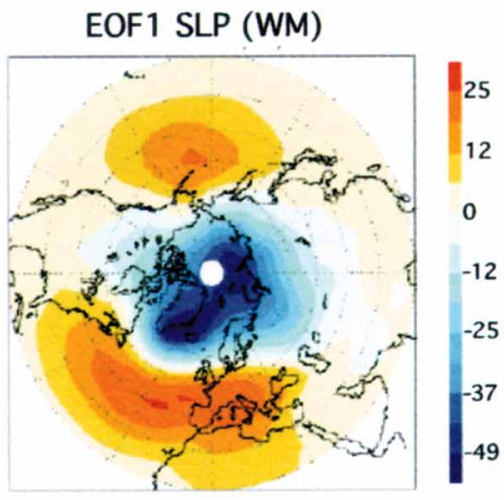

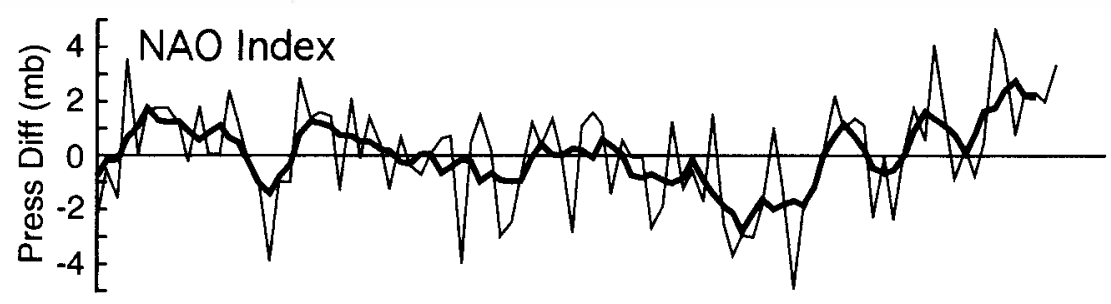

b)

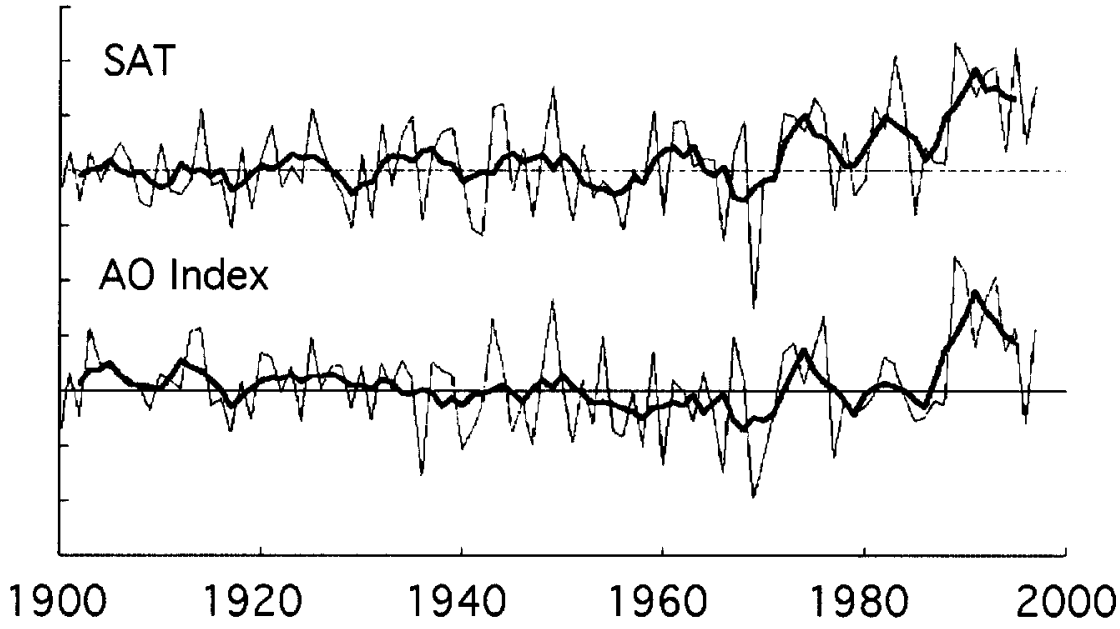

c)

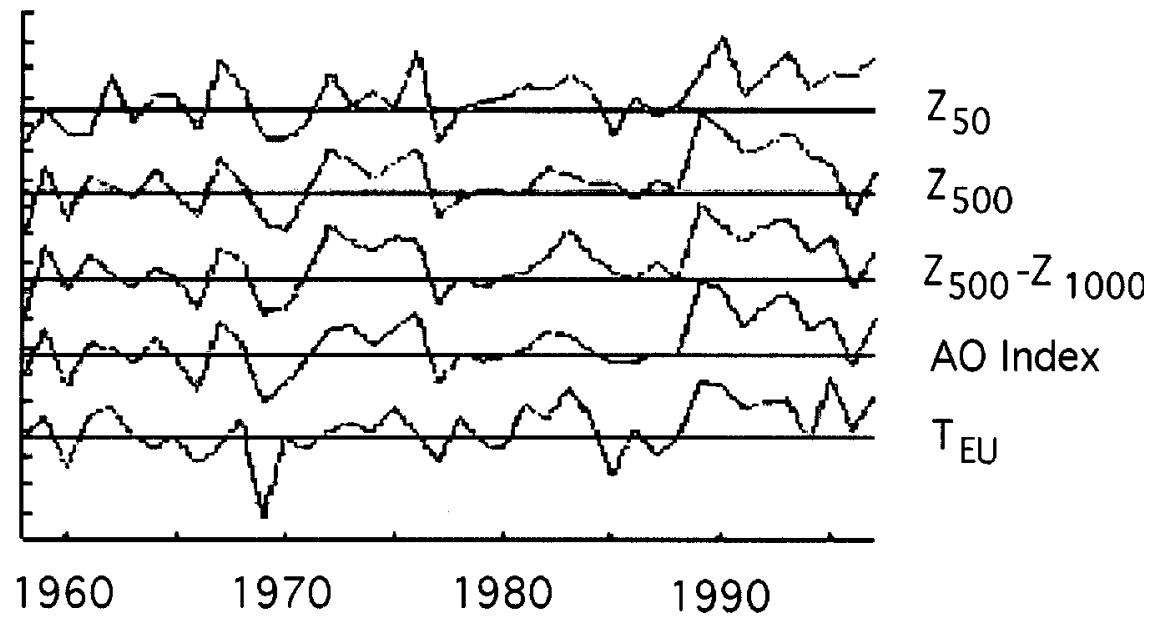

FIG. 5. a) Regression maps for surface air temperature (SAT), surface sea level atmospheric pressure (SLP EOF-1), and geopotential height at $50 \mathrm{mb}$ (Z50) based upon the leading principal component of wintertime (November-April) monthly mean sea-level pressure anomalies (AO-index) for $1947-97$ [from Fig. 1 of Thompson and Wallace (1998)]. Contour intervals (expressed in units per standard deviation of the AO index) are $0.5 \mathrm{~K}$ for SAT, $10 \mathrm{~m}$ for SLP, and $30 \mathrm{~m}$ for Z50. b) Normalized (by standard deviation) wintertime expansion coefficient time series for the SAT and SLP regression maps of Figure 5a for 1900-97 [from Fig. 5 of Thompson and Wallace (1998)]. The normalized wintertime NAO index (sea level pressure at Lisbon, Portugal, minus sea level pressure at Stykkisholmor, Iceland) has been added at the top for comparison. c) Time series of normalized expansion coefficients for the $\mathrm{Z}_{50}, \mathrm{Z}_{500}, \mathrm{Z}_{500-1000}$, and the mean sea level pressure anomalies (AO index), and Eurasian mean $\left(40-70^{\circ} \mathrm{N}, 0-140^{\circ} \mathrm{E}\right) \mathrm{SAT}$ anomalies ( $\left.\mathrm{T}_{\mathrm{EU}}\right)$ [from Fig. 1 of Thompson and Wallace (1998)]. 
shelves, instead of moving off-shelf and across the basin, drifts eastward and exits through the Canadian Archipelago.

Ultimately, we must know how changes in the Arctic are related to larger-scale atmospheric patterns. Swift et al. (1997) and Dickson et al. (1998) suggest that the warming of the Atlantic water in the Arctic Ocean is correlated with the North Atlantic Oscillation: the winter NAO index, which has tended to increase since the 1960s, reached its highest-ever values in the early 1990s. Dickson et al. (2000) argue that the southerly airflow that accompanies the positive index has resulted in warming of the two streams of Atlantic water that enter the Arctic Ocean across the Barents Sea shelf and along the continental slope west of Spitsbergen. It also has resulted in increased precipitation in the Norwegian Sea and decreases in the salinity of the Atlantic water inflow. Swift et al. (1997) similarly relate changes in the Atlantic water temperatures to changes in the Fram Strait inflow, and they show that these temperature changes are correlated with fluctuations in the NAO. Swift et al. (1997) also suggest that the ultimate cause of the warming is reduced winter cooling of the Atlantic water in transit through the Norwegian Sea. This idea agrees with the argument of Dickson et al. (2000).

The Pacific side of the basin has also experienced changes. Overland et al. (1997) report that the position of the tropospheric cold pool is approximately centered over the Canadian Arctic and the Beaufort Sea, displaced from the North Pole by orographic effects of the North American mountain ranges. The result is advection of atmospheric heat and moisture into the Greenland and Barents Seas and the eastern Arctic. The position of this arctic cold pool, in turn, affects the position of the arctic front and the atmospheric circulation in the western Pacific. New analyses reveal a polar pattern in these fluctuations of the cold pool and North Pacific circulation, and this polar pattern has undergone a marked shift since 1990 . This seems to represent a new polar teleconnection pattern.

A more comprehensive picture of the change in the atmospheric pattern is presented by considering the leading empirical orthogonal function (EOF) of sea-level pressure variation for the Northern Hemisphere. Thompson and Wallace (1998) show that this EOF, which they term the Arctic Oscillation (AO), is well correlated with other changes in atmospheric conditions. The $\mathrm{AO}$ resembles the more regional NAO, but the strong negative lobe of its spatial structure is more nearly centered over the North Pole, as shown in Figure 5a (Thompson and Wallace, 1998: Fig. 1). It has strong positive lobes over the North Pacific and North Atlantic. As shown in Figure 5b, the time series of the wintertime AO index is similar to that of the wintertime NAO index, which we have added for comparison. Although the AO was less energetic than the NAO before 1960 , both have tended to increase since the mid-1960s, accompanied by an increase in Northern Hemisphere surface air temperature over the same period. Thompson and Wallace find that the AO index is more highly correlated with surface air temperatures over the
Northern Hemisphere than the NAO is, particularly over the Eurasian continent. The spatial distribution of the temperature increase (Fig. 5a) confirms the finding of Chapman and Walsh (1993) and Martin et al. (1997) that surface air temperatures in the Arctic have been increasing. The AO is associated with low pressure over the Arctic Ocean, so that the particularly rapid increase in the AO index shown after the late 1980s (Fig. 5b) agrees with the results of Walsh et al. (1996) and with the timing and sense of change in upper Arctic Ocean circulation. The timing of the change is also confirmed by Watanabe and Nitta (1997). From their statistical comparison of annual pressure pattern changes to averages for the previous fiveand ten-year periods, they conclude that the Northern Hemisphere $500 \mathrm{hPa}$ pressure underwent significant change in 1989 , with a strong pressure decrease centered over the Arctic Ocean.

One of the notable aspects of the Thompson and Wallace (1998) work is the connection that they find between the leading EOF of surface pressure and that at $50 \mathrm{hPa}$, which is centered over the North Pole. Figure 5c shows that the time series of the $50 \mathrm{hPa}$ and surface coefficients are very well correlated, so that the change in the atmosphere extends from the stratosphere to the surface-and, by our arguments here, also down into the ocean. Thompson and Wallace postulate that the atmospheric change may be driven either by radiatively induced temperature changes in the stratosphere or by a barotropic response of the polar vortex to greenhouse warming in the troposphere.

\section{CHANGES IN SURFACE AIR TEMPERATURE, SEA ICE EXTENT, AND PERMAFROST}

Rigor et al. (2000) have analyzed the IABP surface air temperatures for $1979-97$. They find a trend of $+1^{\circ} \mathrm{C}$ per decade during winter in the eastern Arctic, but a trend of $1{ }^{\circ} \mathrm{C}$ per decade in the western Arctic. In spring there is a warming trend over the whole basin, but it is highest (up to $2^{\circ} \mathrm{C}$ per decade) in the eastern Arctic. The data show even larger trends over the Russian Arctic. Rigor et al. (2000) find that the $\mathrm{AO}$ accounts for more than half the warming trends over Alaska, Eurasia, and the eastern Arctic.

Stone (1997) discusses temperature and cloud-cover measurements at Barrow Alaska from 1965 to 1995. These indicate a 31-year warming trend in winter and spring and cooling in fall. Although Stone does not discuss short-term interannual variations, in the context of this review we notice that since 1989 , there have been enhanced positive trends in temperature and cloud cover for the months of November (bucking the long-term trend), January, February, and April. The strong positive correlation between temperature and cloud cover led Stone to conclude that the warming is associated with changes in cloud distribution due to changes in atmospheric circulation.

Several authors have found long-term trends toward decreasing Arctic sea ice. For example, Maslanik et al. 
(1996) have observed a decrease in the ice cover on the Siberian shelves in recent years. Johannessen et al. (1995) have analyzed satellite passive microwave data for sea ice extent and total area covered by ice from 1978 to 1994 . The analysis is complicated by a change in satellite system (from Nimbus-7 SMMR to DMSP SSM/I) in 1987, but this problem has been resolved by Bjørgo et al. (1997), whose results fundamentally agree with those of Johannessen et al. With corrections for the instrument change, the microwave data of Bjørgo et al. indicate that ice extent has decreased by $4.5 \%$ and total area by $5.7 \%$ over the 16.8 year observation period. Recent analysis by Cavalieri et al. (1997) of passive microwave data for November 1978 through December 1996 indicates that the areal extent of Arctic sea ice had decreased by $2.9 \pm 0.4 \%$ per decade, while the Antarctic sea ice extent has increased $1.3 \%$ per decade. During the 1990s, record or near-record retreat of Arctic sea ice was observed in 1990, 1991, 1993, 1995, and 1997. Parkinson et al. (1999) have updated and expanded the Cavalieri et al. (1997) analysis by examining the trends in the various peripheral seas. They find the largest negative trends in the Barents and Kara Seas. Only the Arctic Ocean proper shows a decrease in annual average ice extent concentrated during the 1990s, and this occurs mainly in the summer months.

On land, studies of permafrost have shown strong warming and thawing trends in many areas of the Arctic (Lachenbruch and Marshall, 1986; Burn, 1992; Pavlov, 1994; Osterkamp and Romanovsky, 1999; Serreze et al., 2000). Osterkamp and Romanovsky (1999) report that warming and thawing have been occurring in the areas of Alaska partially covered by frozen ground. Their model results suggest permafrost in this area warmed in the late 1960s and 1970s. Permafrost temperatures varied little from the late 1970s to the late 1980s and then warmed again through at least 1996 . The warming in recent years is about $0.5^{\circ} \mathrm{C}$ at $20 \mathrm{~m} \mathrm{depth}$, and the thaw rates are about $0.1 \mathrm{~m} \mathrm{yr}^{-1}$. Osterkamp and Romanovsky (1996) find that in the continuous permafrost on the North Slope of Alaska the permafrost was cooling prior to the late 1980s. Since that time, however, and coincident with the changes in the Arctic Ocean, the permafrost has been warming and thawing. Pavlov (1994) indicates that the near-surface temperatures of permafrost in northern Russia have increased $0.6-0.7^{\circ} \mathrm{C}$ over the 1970 s and $1980 \mathrm{~s}$. An opposite trend is reported by Wang and Allard (1995) for northern Quebec. They observe decreasing permafrost temperatures, which they relate to observed lower air temperatures in that region. The permafrost warming trend therefore suggests a spatial variability corresponding to that of air temperature (Rigor et al., 2000).

\section{A PRELIMINARY EXPLANATION}

The Arctic is in the midst of change extending from the stratosphere to below $1000 \mathrm{~m}$ in the ocean. We hypoth- esize that these changes originate with the increase in the Arctic Oscillation index (Thompson and Wallace, 1998). As the AO index rises, the strength of the polar vortex increases, and the surface pressure in the Arctic Basin decreases, weakening the Beaufort high (Walsh et al., 1996). This adds positive vorticity to the sea ice and the ocean circulation (Proshutinsky and Johnson, 1996), resulting in reduced convergence in the Beaufort Gyre. This in turn results in more open water, greater radiative heat input, and increased summer melt (McPhee et al., 1998). The change in circulation may also account for the decreased ice cover on the Siberian shelves (Maslanik et al., 1996). Steele and Boyd (1998) argue that the change in circulation re-routes Siberian river runoff and is thereby responsible for thinning the cold halocline layer. The shift of Siberian runoff to the east may also be responsible in part for the freshening of the upper layers of the Beaufort Sea (McPhee et al, 1998; Macdonald et al., 1999). The increased cyclonic vorticity added to the Arctic Ocean may also act to draw surface water from the lower-salinity western region of the basin and increase the amount of fresh surface water flowing out through Fram Strait. This additional flow could increase stratification in the Greenland Sea and contribute to the weakened deep convection found there in recent years (Aagaard et al., 1991; Schlosser et al., 1991).

The AO pattern (Thompson and Wallace, 1998) indicates a northward component in the average winds across the Atlantic sector, which carries warm air over the Greenland-Norwegian Sea, Scandinavia, and northern Russia. This component should also advect moisture northward to these regions, producing greater cloudiness and enhanced downward longwave radiation (Stone, 1997). An increase in warm air and moisture advection results in an increase in surface air temperature in the Greenland-Norwegian Sea and northern Russia (Thompson and Wallace, 1998; Rigor et al., 2000). The warming over the Norwegian Sea reduces the heat loss from the Atlantic Water before it enters the Arctic Ocean, leading to the warmer Atlantic layer observed by Carmack et al. (1997), Swift et al. (1997), Morison et al. (1998a), and Steele and Boyd (1998). The change in atmospheric circulation is also represented in a rising NAO index and the observed correlation between this index and Fram Strait inflow temperatures, as described by Swift et al. (1997) and Dickson et al. (2000).

The advection of warm air into the Russian Arctic and the corresponding positive temperature trend there result in the warming and thawing of permafrost (Pavlov, 1994). Rigor et al. (2000) show some of this warming spilling eastward from Russia to Alaska, explaining the somewhat complicated pattern of permafrost warming observed by Osterkamp and Romanovsky $(1996,1999)$ in Alaska. The strengthened AO pattern adds a northerly component to the airflow over eastern Canada, which accounts for the surface cooling there (Rigor et al., 2000) and the decrease in permafrost temperatures (Wang and Allard, 1995). 


\section{CONCLUSIONS}

The changes both in the ocean and on land appear to be consistent with the recent positive trend in the $\mathrm{AO}$ and its decadal-scale oscillations. While there is a demonstrated connection between the NAO and recent changes in the Arctic (Swift et al., 1997; Dickson et al., 2000; Maslanik et al., 1998), the AO is the more fundamental atmospheric variability pattern. Furthermore, the low arctic sea level pressure characteristic of the AO appears to be critical to the observed large-scale changes in sea ice motion (Maslanik et al., 1998) and other parameters. It is therefore more natural to relate the recent changes in the Arctic to the larger AO phenomenon. The AO is in fact analogous to the Southern Hemisphere annular mode, and both represent fundamental modes of atmospheric circulation that vary at many time scales (Thompson and Wallace, 2000a, b). This implies that the recent changes in the Arctic are part of a fundamental pattern of global environmental variability.

We do not know to what extent the recent changes in the $\mathrm{AO}$ and in the Arctic are cyclic, represent a trend, or might even point to a modal shift. If they are part of a trend or a modal shift, are they related to greenhouse warming? Only long-term observations will answer these questions definitively, and an effort is being made to initiate such observations (Morison et al., 1998b). There are, however, several reasons to think the changes may be related to long-term global climate change. The observations described by Thompson and Wallace (1998) extend back to 1900, and the decadal-scale fluctuations in the AO index are relatively small prior to 1960 . Since then, as shown in Figure 5 , the AO appears as several strong decadal oscillations superimposed on a growing trend, reaching an all-time maximum in the mid-1990s. Additionally, recent experiments with general circulation models have obtained a similar trend as a response to increasing greenhouse gases (Fyfe et al., 1999; Shindel et al., 1999). Changes in the AO, and their effects on ocean and ice, may be how polar amplification of global warming (Manabe et al., 1991; Manabe and Stouffer, 1994; Rind et al., 1995) manifests itself.

A major unknown is how the changes in the ocean and land feed back into the atmospheric pattern. Changes in ocean circulation and the freshwater balance may already have had an effect on deep convection, and thereby on the long-term heat exchange between the world ocean and atmosphere, since increased freshwater export through Fram Strait or the Canadian Arctic Archipelago may reduce deep convection in the Greenland or Labrador Seas. The connections between recent variability of deep convection in these regions and Arctic change therefore warrant special study. Clearly the changes in ice cover we might expect to result from a weakened Beaufort Gyre and changes on the Russian shelves may decrease the albedo and enhance ice melt by the ice albedo feedback process. This can be expected to result in warmer air temperatures, with effects on atmospheric pressure and circulation. The role of such a feedback in the cycle of the $\mathrm{AO}$ is unknown.
Changes in surface air temperature associated with the AO have been substantial (Rigor et al., 2000), and Overland (pers. comm. 1997) suggests that the areas over which these warmings have occurred are large enough to have an immediate large-scale effect on the polar circulation. The thawing of terrestrial ice due to the observed warming has an immediate impact on Arctic residents, but it also releases freshwater to the ocean and methane to the atmosphere, and perhaps alters albedo over land. These factors would provide positive feedback for polar warming.

\section{ACKNOWLEDGEMENTS}

We gratefully acknowledge the support of NSF grant OPP9712315, NSF grant OCE 9812175, ONR grant N00014-98-10037, NASA grant NAG5-4375, and the Applied Physics Laboratory of the University of Washington. We thank all our colleagues whose work we have reviewed and those who have thoughtfully reviewed this paper. We are especially grateful to David Thompson and Ignatius Rigor for supplying key figures.

\section{REFERENCES}

AAGAARD, K., FAHRBACH, E., MEINCKE, J., and SWIFT, J.H. 1991. Saline outflow from the Arctic Ocean: Its contribution to the deep waters of the Greenland, Norwegian, and Iceland Seas. Journal of Geophysical Research 96:20,433-20,441.

ANDERSON, L.G., BJORK, G., HOLBY, O., JONES, E.P., KATTNER, G., KOLTERMANN, K.P., LILJEBLAD, B., LINDEGREN, R., RUDELS, B., and SWIFT, J.H. 1994. Water masses and circulation in the Eurasian Basin: Results from the Oden 91 expedition. Journal Geophysical Research 99(C2): $3273-3283$.

BJØRGO E., JOHANNESSEN, O.M., and MILES, M.W. 1997. Analysis of merged SMMR-SSMI time series of Arctic and Antarctic sea ice parameters 1978-1995, Geophysical Research Letters 24(4):413-416.

BURN. C.R. 1992, Recent ground warming inferred from the temperature in permafrost near Mayo, Yukon Territory. In: Dixon, J.C., and Abrams, A.D., eds. Periglacial geomorphology. New York: John Wiley and Sons. 327-350.

CARMACK, E.C., MACDONALD, R.W., PERKIN, R.G., McLAUGHLIN, F.A., and PEARSON, R.J. 1995. Evidence for warming of Atlantic water in the southern Canadian Basin of the Arctic Ocean: Results from the Larsen-93 Expedition. Geophysical Research Letters 22(9):1061-1064.

CARMACK, E.C., AAGAARD, K., SWIFT, J.H., MACDONALD, R.W., McLAUGHLIN, F.A., JONES, E.P., PERKIN, R.G., SMITH, J.N., ELLIS, K., and KILIUS, L. 1997. Changes in temperature and contaminant distributions within the Arctic Ocean. Deep-Sea Research Part II 44:1487-1502.

CAVALIERI, D.J., GLOERSEN, P., PARKINSON, C.L., COMISO, J.C., and ZWALLY, H.J. 1997. Observed hemispheric asymmetry in global sea ice changes. Science 278(5340): $1104-1106$. 
COLONY, R.L., and RIGOR, I.G. 1993. International Arctic Buoy Program Data Report for 1 January 1992-31 December 1992. Report APL-UW TM29-93. Applied Physics Laboratory, University of Washington.

CHAPMAN, W.L., and WALSH, J.E. 1993. Recent variations of sea ice and air temperature in high latitudes. Bulletin of the American Meteorological Society 74:33-47.

DICKSON, R.R., OSBORN, T.J., HURRELL, J., MEINCKE, J., BLINDHEIM, J., ADLANDSVIK, B., VIGNE, T., ALEKSEEV, G., and MAZLOWSKI, W. 2000. The Arctic Ocean response to the North Atlantic Oscillation. Journal of Climate 13: 2671-2696.

EWG (ENVIRONMENTAL WORKING GROUP). 1997. Joint U.S.-Russian Atlas of the Arctic Ocean. Oceanography Atlas for the Winter Period. National Ocean Data Center. CD-ROM available from the NODC.

FYFE, J.C., BOER, G.J., and FLATO, G.M. 1999. The Arctic and Antarctic oscillations and their projected changes under global warming. Geophysical Research Letters 26(11):1001-1604.

GORE, A., and BELT, D. 1997. An Arctic breakthrough. National Geographic 191(2):36-57.

GORSHKOV, S.G., ed. 1983. Arctic Ocean. World Ocean Atlas Series, Vol. 3. Oxford: Pergamon. 184 p.

GROTEFENDT, K., LOEGEMANN, K., QUADFASEL, D., and RONSKI, S. 1998. Is the Arctic Ocean warming? Journal of Geophysical Research 103:27,679-27,687.

JOHANNESSEN, O.M., MILES, M.W., and BJØRGO, E. 1995. The Arctic's shrinking sea ice. Nature 373:126-127.

LACHENBRUCH, A.H., and MARSHALL, B.V. 1986. Changing climate: Geothermal evidence from permafrost in the Alaskan Arctic. Science 234:689-696.

LEVITUS, S. 1982. Climatological atlas of the world ocean. U.S. Department of Commerce, National Oceanic and Atmospheric Administration, Report Number 12. 173 p.

MACDONALD, R.W., CARMACK, E.C., McLAUGHLIN, F.A., FALKNER, K.K., and SWIFT, J.H. 1999. Connections among ice, runoff and atmospheric forcing in the Beaufort Gyre. Geophysical Research Letters 26(15):2227-2230.

MANABE, S., and STOUFFER, R.J. 1994, Multiple-century response of a coupled ocean-atmosphere model to an increase of atmospheric carbon dioxide. Journal of Climate 7:5-23.

MANABE, S., STOUFFER, R.J., SPELLMAN, M.J., and BRYAN, K. 1991. Transient response of a coupled ocean-atmosphere model to gradual changes of atmospheric $\mathrm{CO}_{2}$, I. Annual mean response. Journal of Climate 4:785-818.

MARTIN, S.E., MUNOZ, E., and DREUCKER, R. 1997. Recent observations of a spring-summer warming over the Arctic Ocean. Geophysical Research Letters 24(10):1259-1262.

MASLANIK, J.A., SERREZE, M.C., and BARRY, R.G. 1996. Recent decreases in Arctic summer ice cover and linkages to atmospheric circulation anomalies. Geophysical Research Letters 23(13): $1677-1680$.

MASLANIK, J.A., FOWLER, C., EMERY, W., and WEATHERLY, J. 1998. On the interannual variability of arctic sea ice transport: Relationships to atmospheric circulation models and significance for GCM assessments. World Climate Research Program, Proceedings. Arctic Climate System Study Conference on Polar Processes and Global Climate. Rosario, Orcas Island, Washington, 3-6 November 1997. WCRP-106, WMO/TD No. 908. 156-158.

MASLOWSKI, W., McLEAN, J., NEWTON, R., and SCHLOSSER, P. 1998. Modeling interannual variability of the Arctic Ocean and sea ice circulation. Abstract of oral presentation at the 1998 Fall American Geophysical Union meeting. San Francisco. Supplement to Eos, Transactions of the American Geophysical Union 79(45):F414.

McLAUGHLIN, F.A., CARMACK, E.C., MACDONALD, R.W., and BISHOP, J.K.B. 1996. Physical and geochemical properties across the Atlantic/Pacific water mass front in the southern Canadian Basin. Journal of Geophysical Research 101(C1): $1183-1195$.

McPHEE, M.G., STANTON, T.P., MORISON, J.H., MARTINSON, D.G. 1998. Freshening of the upper ocean in the Central Arctic: Is perennial sea ice disappearing? Geophysical Research Letters 25:1729-1732.

MELNIKOV, I., SCHERR, B., WELCH, B., and WHEELER, P. 1998. Preliminary biological and chemical oceanographic evidence for a long-term warming trend in the Arctic Ocean (current materials of the SHEBA Ice Camp, Beaufort Sea). In: Morison, J.H., Aagaard, K., and Steele, M., eds. Report on the Study of the Arctic Change Workshop, held 10-12 November 1997, Seattle, Washington. Arctic System Science OceanAtmosphere-Ice Interactions Report No. 8. Available from the Polar Science Center, 1013 NE 40th St., Seattle, Washington 98105, U.S.A. 60.

MORISON, J.H., STEELE, M., ANDERSEN, R. 1998a. Hydrography of the upper Arctic Ocean measured from the nuclear submarine USS Pargo. Deep-Sea Research I 45:15-38.

MORISON, J.H., AAGAARD, K., and STEELE, M., eds. 1998b. Report on the Study of the Arctic Change Workshop, held 1012 November 1997, Seattle, Washington. Arctic System Science Ocean-Atmosphere-Ice Interactions Report No. 8. Available from the Polar Science Center, 1013 NE 40th St., Seattle, Washington 98105, U.S.A.

OSTERKAMP,T.E., and ROMANOVSKY,V.E. 1996.Characteristics of changing permafrost temperatures in the Alaskan Arctic, U.S.A. Arctic and Alpine Research 28(3):267-273.

1999. Evidence for warming and thawing of discontinuous permafrost in Alaska. Permafrost and Periglacial Processes 10(1):1737.

OVERLAND, J.E., ADAMS, J.M., and BOND, N.A. 1997. Regional variation of winter temperatures in the Arctic. Journal of Climate 10(5):821-837.

PARKINSON C.L., CAVALIERI, D.J., GLOERSEN, P., ZWALLY, H.J., and COMISO, J.C. 1999. Arctic sea ice extents, areas, and trends, 1978-1996. Journal of Geophysical Research104(C9):20,837-20,856.

PAVLOV, A.V. 1994. Current changes of climate and permafrost in the Arctic and Sub-Arctic of Russia. Permafrost and Periglacial Processes 5:101-110.

PAWLOWICZ, R., and FARMER, D. 1997. Temperature changes in the western Eurasian Basin and northern Fram Strait, 19641994. Eos, Transactions of the American Geophysical Union 76(3):OS13. 
PROSHUTINSKY, A., and JOHNSON, M. 1996. Two regimes of Arctic Ocean circulation from ocean models and observations. Abstract of poster presented at the 1996 Ocean Sciences Meeting. San Diego, California. Eos (supplement) 76(3):OS29.

1997. Two circulation regimes of the wind-driven Arctic Ocean. Journal of Geophysical Research 102(C6)12,493-12,514. QUADFASEL, D. 1991. Warming in the Arctic. Nature 350:385. RIGOR, I.G., and COLONY, R.L. 1995. International Arctic Buoy Program Data Report for 1 January 1993-31 December 1993. Report APL-UW TM4-95. Applied Physics Laboratory, University of Washington.

RIGOR, I.G., COLONY, R.L., and MARTIN, S. 2000. Variations in surface air temperature observations in the Arctic, 1979-97. Journal of Climate 13:896-914.

RIND, D., HEALY, R., PARKINSON, C., and MARTINSON, D. 1995. The role of sea ice in $2 \mathrm{X} \mathrm{CO}_{2}$ climate model sensitivity, I: The total influence of sea ice thickness and extent. Journal of Climate 8:449-463.

RUDELS, B., JONES, E.P., ANDERSON, L.G., and KATTNER, G. 1994. On the intermediate depth waters of the Arctic Ocean. In: Johannessen, O.M., Muench, R.D., and Overland, J.E., eds. The polar oceans and their role in shaping the global environment. Washington, D.C.: American Geophysical Union 85. 33-46.

SHINDELL, D.T., MILLER, R.L., SCHMIDT, G., and PANDOLFO, L. 1999. Simulation of recent northern winter climate trends by greenhouse-gas forcing. Nature 399:452455.

SCHLOSSER, P., BONISCH, G., RHEIN, M., and BAYER, R. 1991. Reduction of deep-water formation in the Greenland Sea during the 1980s: Evidence from tracer data. Science 251: $1054-1056$.

SERREZE, M.C., CARSEY, F., BARRY, R.G., and ROGERS, J.C. 1997. Icelandic low cyclone activity: Climatological features, linkages with the NAO, and relationships with recent changes in the Northern Hemisphere circulation. Journal of Climate 19(3):453-464.

SERREZE, M.C., WALSH, J.E., CHAPIN, F.S., III, OSTERKAMP, T., DYURGEROV, M., ROMANOVSKY, V., OECHEL, W.C., MORISON, J., ZHANG, T., and BARRY, R.G. 2000. Observational evidence of recent change in the northern highlatitude environment. Climatic Change 46:159-207.
STEELE, M., and BOYD, T. 1998. Retreat of the cold halocline layer in the Arctic Ocean. Journal of Geophysical Research 103:10,419-10,435.

STONE, R.S. 1997. Variations in western Arctic temperatures in response to cloud radiative and synoptic scale influences. Journal of Geophysical Research 102(D18):21,769-21,776.

SWIFT, J.H., JONES, E.P., AAGAARD, K., CARMACK, E.C., HINGSTON, M., MACDONALD, R.W., McLAUGHLIN, F.A., and PERKIN, R.G. 1997. Waters of the Makarov and Canada basins. Deep-Sea Research Part II 44:1503-1529.

THOMPSON, W.J., and WALLACE, J.W. 1998. The Arctic Oscillation signature in the wintertime geopotential height and temperature fields. Geophysical Research Letters 25: $1297-1300$.

2000a. Annular modes in the extratropical circulation Part I: Month-to-month variability. Journal of Climate 13:10001016.

2000b. Annular modes in the extratropical circulation Part II: Trends. Journal of Climate13:1018-1036.

TRESHNIKOV, A.F. 1977. Water masses of the Arctic Basin. In: Dunbar, M.J., ed. Polar oceans. Calgary, Alberta: Arctic Institute of North America. 17-31.

WALSH, J.E., CHAPMAN, W.L., and SHY, T.L. 1996. Recent decrease of sea level pressure in the central Arctic. Journal of Climate 9:480-486.

WANG, B., and ALLARD, M. 1995. Recent climatic trend and thermal response of permafrost at Salluit, Northern Quebec, Canada. Permafrost and Periglacial Processes 6:221-234.

WATANABE, M., and NITTA, T. 1999. Decadal changes in the atmospheric circulation and associated surface climate variations in the Northern Hemisphere winter. Journal of Climate 12: 494-510.

ZHANG, J.L., ROTHROCK, D.A., and STEELE, M. 1998. Warming of the Arctic Ocean by a strengthened Atlantic inflow: Model results. Geophysical Research Letters 25(10):17451748.

ZHANG, Y., and HUNKE, E. In press. Recent Arctic change simulated with a coupled ice-ocean model. Journal of Geophysical Research. 